\title{
Do sectoral externalities affect firm productivity regardless of technology level? Evidence from Spain*
}

\author{
Esther Goya \\ Esther Vayá \\ Jordi Suriñach \\ AQR-IREA Research Group \\ University of Barcelona
}

\begin{abstract}
The aim of this study is to assess the impact that $R \& D$ expenditure and intra- and inter-industry externalities have on Spanish firm's productivity. Certainly a large body of literature has analysed the relationship between innovation and productivity, however there has been little discussion about the importance of sectoral externalities, especially with the focus on Spain. The database used is the Technological Innovation Panel (PITEC), which includes 7,507 firms for the year 2010 and has been little used in this type of study. The results confirm that $R \& D$ expenditures have a positive impact on productivity, mainly in low-tech and small and medium-sized firms. Intra-industry externalities also have a positive and significant effect especially in low-tech firms, while inter-industry externalities are relevant for high-tech firms. Finally, large firms are those that benefit from both intra- and inter-externalities.
\end{abstract}

Keywords: productivity, innovation, sectoral externalities, firm size.

JEL classification: D24, O33.

\section{Resumen}

Este trabajo estudia el impacto de los gastos en $I+D$ y de las externalidades intrasectoriales $e$ intersectoriales sobre la productividad de empresas españolas, ámbito para el que en el caso de España existe una escasa literatura. La base de datos que se utiliza es el Panel de Innovación Tecnológica (PITEC) que consta de 7,507 empresas para el año 2010, y que ha sido poco explotado para este tipo de estudios. Los resultados confirman que los gastos en $I+D$ tienen un efecto positivo sobre la productividad, sobre todo en empresas de bajo nivel tecnológico y de menor tamaño. Las externalidades intrasectoriales también tienen un impacto positivo, especialmente en niveles tecnológicos bajos, mientras que las externalidades intersectoriales son relevantes en niveles tecnológicos altos. Respecto al tamaño, las empresas grandes son las únicas que se benefician de ambas externalidades.

Palabras clave: productividad, innovación, externalidades sectoriales, tamaño empresa.

Clasificación JEL: D24, O33.

* This research has received funding from the European Union's Seventh Framework Programme FP7-SSH-2010-2.2-1 (2011-2014), under grant agreement $n .^{\circ} 266834$. The authors are grateful for the funding obtained from the Ministry of Education and Science for the project entitled «Determinants for the spread of innovation and their effects on productivity», ECO2009-12678/ECON, 2010-2012.

Esther Goya is grateful for the support received from the CUR of the DIUE of the Generalitat de Catalunya and from the European Social Fund.

Esther Vayá is grateful for the funding obtained from the Ministry of Education and Science for the project entitled «Regional economic growth and inequality in Spain», ECO2010-16006/ECON, 2011-2013. 


\section{Introduction}

Since the pioneering work of Griliches $(1979,1986)$, the relationship between innovation and productivity has been widely studied by many authors on both national and sectoral as well as firm levels. The Cobb-Douglas production function is normally used for the empirical analysis, extending the traditional inputs of physical capital and labour to include innovation expenditures. The results obtained depend on the geographical area analysed, the database and the methodology used. The evidence certainly points to a positive and significant relationship between innovation and productivity on a firm level (see Mairesse and Sassenou, 1991, for a detailed study, and also -to name but a few- Hall and Mairesse, 1995, for France; Harhoff, 1998, for Germany; Lotti and Santarelli, 2001, for a comparative study of Germany and Italy; and Parisi et al., 2006, for Italy).

However, the impact of innovation on productivity varies depending on a number of factors, including the economic sector. On this aspect most articles agree that the impact that $\mathrm{R} \& \mathrm{D}$ expenditures has on productivity is greater in high-tech sectors than in low-tech sectors (see Verspagen, 1995, for 9 OECD countries; Tsai and Wang, 2004, for Taiwan; Ortega-Argilés et al., 2010 and 2011, for European firms). Another factor that may have an influence on productivity is firm size, although as far as this aspect is concerned there is no consensus regarding the magnitude of this effect. Thus while some authors, using a structural model, obtain an inverse relationship between size and productivity (see Huergo and Moreno, 2004, and Hall et al., 2009), others find the opposite to be true (Griffith et al., 2006). Another interesting aspect that has hardly been analysed in the literature is whether size influences the returns firms obtain from innovation, bearing in mind that the larger the firm, the more innovation it carries out (see Huergo and Jaumandreu, 2004). According to Castany et al. (2009), the size of Spanish firms has an influence on the returns obtained from investment in both innovation and human capital, with the largest firms being the ones that benefit most from these investments.

If we focus on the case of Spain, the relationship between innovation and productivity has been dealt with by a number of authors, also finding innovation to have a positive impact on productivity. However, one limitation that generally can be found in most studies is that the analysis is restricted to manufacturing firms based on the use of the Encuesta sobre Estrategias Empresariales (ESEE) ${ }^{1}$. Among the most up-to-date papers that use this database are those by Huergo and Moreno (2004), Huergo and Jaumandreu (2004), Maté-García and Rodríguez-Fernández (2002, 2008), Rodríguez-Fernández and Maté-García (2006), Rochina-Barrachina et al. (2010) and Casiman et al. (2010), to name but a few. Therefore there are very few papers that carry out a joint analysis of the industrial and service sectors, although

${ }^{1}$ The ESEE is a firm-level survey of Spanish manufacturing which has been collecting annual information since 1990. 
some notable studies are those by Segarra-Blasco (2010) and Segarra-Blasco and Teruel (2011), who use data from the CIS4 for Catalonia.

When the impact of innovation on productivity is examined, these externalities need to be taken into account given that the benefits deriving from innovation in a firm (or sector) spill over towards others due to the firm's inability to seize all the benefits deriving from its investment. Regarding this aspect, there seems to be no general consensus as to the effect these externalities have on productivity. Although there are numerous studies that find a positive relationship (see Griliches, 1992, and Nadiri, 1993), other more recent papers arrive at different conclusions (see for example Klette, 1994, for Norway; Los and Verspagen, 2000, for American firms; Harhoff, 2000, for Germany; and Wakelin, 2001, for the United Kingdom among others) ${ }^{2}$. In the case of Spain, the literature is much smaller. Some articles, such as those by López-Pueyo and Sanaú (1999) and Gumbau-Albert and Maudos (2006), find that externalities are positive and significant in explaining productivity. However, other authors obtain different results depending on the firm's economic sector or technology level (Beneito, 2001), and no consensus exists in this area.

The purpose of this paper is to analyse to what extent technology level and firm size affect the return that firms obtain from their investment in innovation. Also, and bearing in mind the small amount of literature on the subject in Spain, it aims to analyse to what extent the above factors influence the benefit that firms obtain from innovations carried out by others (either all the other firms in the same sector or the other sectors). This will be carried out by taking into consideration a sample of 7,507 Spanish firms belonging to both the industrial and service sectors. Thus the article will make a thorough analysis of the relationship between innovation and productivity, contributing as added value different aspects such as considering the indirect effect of size on productivity through innovation. It should be pointed out that the analysis of externalities is carried out taking into account technology level and firm size. It should also be mentioned that the study breaks new ground in that it focuses on both the industrial and service sectors, thereby aiming to overcome a severe limitation given that, as we have already seen, most studies in this area focus only on the manufacturing sector.

The structure of the paper is as follows. After this introduction, Section II presents the economic model, Section III describes the database and empirical model, Section IV presents the results obtained, and finally the conclusions are set out in Section V.

\section{Economic model}

The model adopted to estimate the relationship between innovation and productivity is the extended Cobb-Douglas production function, which apart

\footnotetext{
${ }^{2}$ It is worth mentioning that the results depend on the definition of externality, the technology matrix flow used, as well as, the country.
} 
from including conventional production factors (physical capital and labour) also incorporates human capital and innovation:

$$
y_{i s}=A_{i s} \cdot k_{i s}^{\alpha} \cdot l_{i s}^{\beta} \cdot h_{i s}^{\gamma} \cdot i_{i s}^{\delta}
$$

Thus the labour productivity of firm i belonging to sector $s\left(y_{i s}\right)$ is a function of physical capital per employee $\left(k_{i s}\right)$, of labour $\left(l_{i s}\right)$, of human capital $\left(h_{i s}\right)$, of innovation per employee $\left(i_{i s}\right)$ and of the firm's technology level $\left(A_{i s}\right)$, with $\alpha, \beta$, $\gamma, \delta$ being the returns on physical capital, labour, human capital and innovation respectively.

Human capital $(h)^{3}$ has been included in the Equation [1] because as the workers become better trained and acquire more skills they can carry out tasks more efficiently. The literature shows how human capital has a significant influence on firm productivity ${ }^{4}$ in such a way that the more qualified workers the firm has, the more productive it will be. In the same way, innovation $(i)$ has been included as a production function input and a variable of interest in our study. As mentioned in Section I, this is a very important factor for increasing firm productivity.

With respect to the technology level $A_{i s}$ in Equation [1], it will be assumed in this paper that an external effect exists due to the public nature of knowledge ${ }^{5}$. Hence one firm's technology depends on the innovation made by all the other firms:

$$
A_{i s}=A \cdot\left(S_{i s}^{I N T R A}\right)^{\phi_{1}} \cdot\left(S_{i s}^{I N T E R}\right)^{\phi_{2}}
$$

where $A$ is a constant to denote a common technology level for all the firms; $S_{i s}^{I N T R A}$ is the intra-industry externality of firm $\mathrm{i}$ in sector $\mathrm{s}$ and includes the innovating effort made by all the other firms in the same sector; and $S_{i s}^{I N T E R}$ is the inter-industry externality understood as the innovation made by the firms in all the other sectors.

As regards externalities, it has to be taken into account that knowledge transfer between firms can come about in different ways: learning what other firms do either via the movements of workers themselves or through reading articles in journals, attending conferences, disclosure of a patent, etc. The result is that one firm uses the knowledge generated in another firm without paying for it directly.

${ }^{3}$ It must be pointed out that there are few microeconomic studies that incorporate human capital and innovation as factors in the production function, especially in the case of Spain.

${ }^{4}$ See for example BLACK and LYNCH (1996) and HALTIWANGER et al. (1999) for the United States, TURCOTTE and RENNISON (2004) for Canada, ARVANITIS and LOUKIS (2009) for Greece and Switzerland, YANG, LIN, MA (2010) for China, and LEE (2011) for Malaysia.

5 This public nature is due to the fact that knowledge is non-rival (its use by one firm does not prevent others from using it at the same time) and non-excludable (no firm can be excluded from using it). 
Thus by combining Equations [1] and [2] we see that a firm's labour productivity is explained through its own investments (in physical capital, labour, human capital and innovation) as well as through the innovation effort made by all the other firms, captured as an externality:

$$
y_{i s}=A \cdot k_{i s}^{\alpha} \cdot l_{i s}^{\beta} \cdot h_{i s}^{\gamma} \cdot i_{i s}^{\delta}\left(S_{i s}^{I N T R A}\right)^{\phi_{1}} \cdot\left(S_{i s}^{I N T E R}\right)^{\phi_{2}}
$$

From Equation [3] it can be concluded that (under the assumption that $\phi_{1}$ and $\phi_{2}$ ), even though a firm makes no investment in innovation, it could still benefit from the innovation carried out by all the other firms and thereby increase its own productivity.

\section{Data and empirical model}

The database used is the Technology Innovation Panel (PITEC), which provides information on the technological innovation activities of Spanish firms for the period 2003-2010 . It is a data panel based on a representative selection of firms, which makes it possible to carry out repeated observations of the economic units included over time and thereby develop much more precise estimations of the evolution of $\mathrm{R}+\mathrm{D}+\mathrm{I}$ activities in the business sector (innovation expenditures, composition of the samples, etc.), determine the impact of innovation (different effects on productivity) and identify the various strategies in the decisions adopted by firms when introducing innovations into their business (for instance the different compositions of internal and external R\&D expenditures as a part of total expenditures). The panel is made up of four non-excludable samples: (i) firms with 200 or more employees, (ii) firms with internal R\&D expenditures, (iii) firms with fewer than 200 employees with external $R \& D$ expenditures but which carry out no internal $R \& D$, and (iv) firms with fewer than 200 employees with no innovation expenditures. There is a double advantage to using this database for Spain. Firstly it provides information on both the industrial and service sectors, which means that one serious limitation can be overcome given that most studies in this area focus only on the manufacturing sector, generally using the ESEE. And secondly, it contains a high level of sectoral information broken down into details covering 38 industrial and service sectors (see appendix B). This enables a much richer study to be made of the different behaviours between sectors with different technology levels and, in turn, makes a more interesting study of interindustry externalities possible.

${ }^{6}$ PITEC is built upon the Spanish Innovation Survey carried out by the INE, which in turn is based on the Community Innovation Survey (CIS) which follows guidelines laid down by the OECD's Oslo Manual and, through the use of a standardized questionnaire, enables comparisons to be made between countries. 
The number of firms included in the sample for 2010 is 12,821. After a filtering process $^{7}$, only those firms belonging to the industrial and service sectors were selected, thereby excluding the primary sector and construction, and at the same time only those firms with 10 or more employees have been taken into account ${ }^{8}$. Note that the influence of extreme outliers was treated (see appendix A). In the end the sample to be worked with consisted of 7,507 observations.

Based on the expression of the theoretical model in Section II, and with the information supplied by the PITEC database, the following econometric model has been specified:

$$
y_{i s}=\lambda+\alpha k_{i s}+\beta l_{i s}+\gamma h_{i s}+\delta i_{i s}+\phi_{1} S_{i s}^{I N T R A}+\phi_{2} S_{i s}^{I N T E R}+\text { controls }+\varepsilon_{i s}
$$

where $y_{i, s}$ approximates the quotient of sales per employee ${ }^{9}, k_{i s}$ is physical capital stock per employee, $l_{i s}$ is the number of employees ${ }^{10}, h_{i s}$ is the percentage of employees with higher education, and $i_{i s}$ is defined as R\&D stock per employee ${ }^{11,12,13}$. The regression controls are represented by a dummy variable equals 1 if the firm belongs to a group, as well as, technology level and firm's size dummies.

As regards externalities, due to the great many different ways in which spillovers can appear, measuring them is a complicated task. In our case the R\&D expenditure will be used to approximate them. Thus to begin with, the intra-industry externalities corresponding to firm i belonging to sector s are defined as:

$$
S_{i s}^{I N T R A}=\sum_{j \neq i} I_{j s}
$$

or in other words the total R\&D expenditure made by all the other firms in the same sector. With this definition we capture the technological effort of the sector in which the firm is located. However, clearly not all the R\&D expenditure made by all the other firms will benefit firm $i$, but it will serve as an indicator of the magnitude of technological knowledge current in the sector.

7 This filtering process consisted of eliminating those observations that include some incident (due to problems of confidentiality or takeovers, mergers, etc) and those with any anomaly (such as null sales).

8 The population area taken into account is that defined in the Spanish Innovation Survey on which PITEC is based.

9 Unfortunately, PITEC does not contain information about intermediate consumptions.

${ }^{10}$ Constant returns to scale are not assumed. Thus, a positive (negative) coefficient of the employment variable, will suggest increasing (decreasing) returns to scale.

11 It includes both internal and external R\&D.

12 Logarithms have been taken of variables. No logarithms are applied in the case of variable as it is a percentage.

13 Appendix D shows how physical capital and R\&D stocks have been constructed. 
Secondly, the inter-industry externalities corresponding to firm i belonging to sector s are defined in the following way:

$$
S_{i s}^{I N T E R}=\sum_{m \neq s} w_{s m} \cdot I_{j m}
$$

or in other words the weighted sum of all R\&D expenditures carried out by the firms in all the other sectors. Weighting $w_{s m}$ is defined as the quotient between the intermediate purchase by sector $s$ of goods and services supplied by sector $m$ and the total sum of intermediate purchase of sector $s$. Thus the influence that R\&D expenditure made by firms in sector $\mathrm{m}$ has on the productivity of firm $i$ in sector $s$ is based on the relative importance that said sector $m$ has as supplier to sector $s$. To construct the $w_{s m}$ weights we have used the symmetric input-output table for Spain for 2005 (the latest year available), and for this an exercise of correspondence has had to be carried out between the branches of business activity by which the PITEC data are classified and the branches of business activity in the input-output table.

In line with the aim of this paper and for the purposes of analysing whether the effects of the returns from innovation and externalities on productivity vary depending on the sector's technology and firm size, the total sample of 7,507 firms has been divided up according to:

(i) The technology level of the sector in which the firm operates. For this we have used the Eurostat classification and grouped the firms by sector into the following categories:

- Low and medium-low tech industries (LTI)

- Medium-high and high-tech industries (HTI)

- Non-knowledge-intensive services (NKIS)

- Knowledge-intensive services (KIS)

(ii) The size of the firm, distinguishing between:

- Small firms: from 10 to 49 employees.

- Medium-sized firms: from 50 to 199 employees.

- Large firms: 200 or more employees.

To see the distribution of firms according to sub-samples see appendix C.

Table 1 shows the descriptive statistics for the main variables in the model across technology level and firm size. Firstly it can be seen that the great bulk of firms (34 per 100) clearly falls within the category of low technology level industries, as opposed to the lowest percentage corresponding to non-knowledge-intensive services (19 per 100). As regards productivity, it seems that more advanced firms present higher values (HTI and KIS). In addition, industrial firms obtain greater productivity than services. If it is broken down according to firm size, it can be seen that small firms make up the bulk of the sample (42 per 100). As regards productivity, mediumsized firms are seen to present the highest levels, followed by large firms and finally the smaller firms. Secondly, low-tech industries show a higher physical capital ratio than high-tech industries. By contrast, knowledge-intensive services present a higher capital stock than non-knowledge-intensive services. 
TABLE 1

DESCRIPTIVE STATISTICS

\begin{tabular}{|c|c|c|c|c|c|c|}
\hline & $N$ & $\%$ & $y$ & $k$ & $i$ & $h(\%)$ \\
\hline \multicolumn{7}{|c|}{ Technolgy level* } \\
\hline LTI & 2,580 & 34.37 & 5.68 & 5.41 & 2.38 & 12.79 \\
\hline HTI & 1,813 & 24.15 & 5.81 & 4.85 & 3.72 & 22.22 \\
\hline NKIS & 1,437 & 19.14 & 5.06 & 4.79 & 0.14 & 15.19 \\
\hline KIS & 1,677 & 22.34 & 5.57 & 5.17 & 2.89 & 49.14 \\
\hline \multicolumn{7}{|c|}{ Firm size } \\
\hline Small & 3,172 & 42.25 & 5.38 & 4.94 & 3.49 & 27.90 \\
\hline Medium & 2,220 & 29.57 & 5.60 & 4.91 & 3.24 & 22.05 \\
\hline Large & 2,115 & 28.17 & 5.42 & 5.04 & 2.33 & 18.94 \\
\hline Total & 7,507 & 100.00 & 5.44 & 5.02 & 2.52 & 23.65 \\
\hline
\end{tabular}

NOTES: The results associated with labour productivity variable (y) are obtained after adding the information of the sales of all firms in the same technology level (or firm size) and divide by the sum of all employees of all firms at the same technology level (or firm size). Physical capital (k) and R\&D expenditures (i) stocks per employee have been obtained similarly. Human capital (h) is defined as percentage of workers with high education. * Low and mediumlow tech industries (LTI), medium-high and high tech industries (HTI), knowledge no intensive services (NKIS), knowledge-intensive services (KIS).

On the other hand, physical capital differs slightly according to firm size being large firms the ones that perform higher investment. Thus, it does not seem to be a clear pattern according to technology level or firm size. As far as R\&D stock is concerned, it can be seen that the greater the technology level of the sector in which firm operates, the greater its R\&D effort is in both industry and service sector. Particularly, firms that operate in high-tech industries present the highest values. When it is broken down according to firm size Table 1 shows that the larger the firm, the less R\&D intensive is in relative terms. Finally, in the case of human capital, the average percentage of qualified employees is much higher in those firms which operate in more advanced sectors. In particular, those firms belonging to knowledgeintensive services have approximately 49 per 100 of workers with higher education. According to firm size, the larger the firm, the less human capital has in relative terms.

In order to test whether the differences in these variables are significant according to technology level and firm size a Kruskal-Wallis test is performed for each variable. The results clearly reject the null hypothesis ( $\mathrm{p}$-value $=0.0001$ in all cases) of equal population medians ${ }^{14}$.

${ }^{14}$ Kruskal-Wallis test is a nonparametric alternative safer than some parametric test in case we doubt bout normality assumptions or suspect of outlier problems. 


\section{Results}

It is well known that production function is affected by endogeneity problems given the correlation between inputs and firm-specific productivity shocks. Once a firm faces productivity shocks, it tends to increase or decrease their inputs use. In order to obtain consistent estimation Instrumental Variable approach (IV) is commonly used in the literature. However dealing with stock (rather than flows) minimize the risk if endogeneity (see Ortega-Argilés et al., 2010 footnote 4), for this reason we check if, in fact, there is such a problem. Durbin-Wu-Hausman tes ${ }^{15}$ shows that IV estimation is needed only in the total sample, knowledge-intensive services and large firms ${ }^{16}$, while in the rest of the sub-samples the test clearly no rejects the null hypothesis of exogeneity. Consequently, we carry out an estimation of Equation [4] using two-stage least-squares estimator for these sub-samples, and Ordinary Least Squares estimation (OLS) for the rest of them (low-tech and hightech industries, non-knowledge-intensive services, small and medium firms).

The model is estimated using information for 2010. Here it should be mentioned that assuming a contemporary relationship between productivity and $R \& D$ (both own innovation and externalities) seems inappropriate due to there is not an immediate effect. Therefore, $R \& D$ expenditure, as well as, intra- and inter-industry externalities have been lagged two years.

Table 2 shows the results of the estimation for the sample as a whole and also for the sub-samples according to technology level of the sector in which the firm operates and firm size, with the aim of finding out whether there are differences in the returns firms obtain from their own R\&D expenditures and from externalities.

First of all, as shown in Table 2, Wald test points out that size and technology level are significant in the whole sample (column 1) suggesting that there are differences according these factors. This result reinforces the idea of studying each sub-sample separately.

Next, it can be seen that when the sample as a whole is used (column 1) capital stock has a positive impact on productivity. When broken down by technology level (columns 2 to 5), it can be seen that investment in physical capital has a positive impact in all firms. In particular, non-knowledge-intensive services show the greatest impact. Finally, in the breakdown by size sub-samples (columns 6 to 8 ) there appears to have a positive influence on the returns firms obtain from their physical capital stock, since the greater the firm size, the more benefits it obtains from its investment.

As shown in Table 2, the impact of $R \& D$ stock on productivity is positive in the sample as a whole (column 1) and by technology level (columns 2 to 5), except for knowledge-intensive services ${ }^{17}$. In contrast to earlier findings, however, low-tech

${ }^{15}$ Robusted version of the traditional HAUSMAN test.

${ }^{16}$ Following the test, only physical capital is endogenous (not R\&D).

${ }^{17}$ It is worth to mention that this sector includes firms belonging to a very heterogeneous branch of business activities known as «Other activities», which covers: legal and accounting activities, advertising, personnel selection, and placement, investigation and security services, industrial cleaning activities, etc. 
firms are the ones that obtain greater return from R\&D expenditures, both in industry and service sector (column 2 and 4). This result could suggest that even though lowtech firms perform lower R\&D expenditures (see Table 1), their efforts lead to higher probability of obtaining an effective innovation (see Hall et al., 2009 and Goya et al., 2012) and indirectly they increase their productivity. A possible explanation for this might be that firms in these types of sectors needs less R\&D because their innovations are not technology-linked. If a distinction is made according to firm size (columns 6 to 8), R\&D stock is significant only for small and medium-sized firms, and it seems to be not relevant for large firms, unlike what happens with physical capital. Comparing the returns from physical capital and innovation, it can be seen that the return on capital stock is always greater than that from $R \& D$ stock, regardless of technology level or firm's size.

As far as human capital $\left(h_{i}\right)$ is concerned, and according to the literature, its impact on firm productivity is positive and significant. When it is estimated by technology level it can be seen that human capital has a positive impact except for those firms which operate in knowledge-intensive services (column 5). In particular, the less advanced the firm, the greater the impact of hiring qualified workers (column 2 and 4). On the other hand, the result obtained for knowledge-intensive services is counterintuitive because precisely those firms belonging to this sector are the ones that show the highest percentage of qualified workers (see Table 1). A possible explanation could be the over-education problem existing in Spain which causes that qualified workers are less productive because they are performing tasks that do not require their education level (Tsang, 1991). When the data are broken down according to firm size, it can be seen that the larger the firm, the higher the impact of human capital on firm productivity.

Concerning intra-industry externalities, it can be seen that they are not significant on an overall level (column 1). Nevertheless, the breakdown by technology level makes it possible to see that low tech firms benefit from innovation carried out by other firms in their sector. In contrast to Beneito (2001) findings, those firms belonging to advanced sectors obtain less benefit from the R\&D expenditure done by all the other firms in their sector than those firms that form part of less technologically advanced sectors (columns 2 and 4), since they present greater coefficients, especially nonknowledge-intensive service. It should be remembered that, as can be seen in Table 1, non-knowledge-intensive services show the lowest R\&D stock per employee, which would explain why they benefit more from investments made by the other firms in its own sector. This might lead us to believe that there is a «technology threshold» beyond which firms benefit less or not benefit at all from the R\&D expenditure made by all the other firms in the sector. Also, it could reflect the fact that in high-tech sectors there is a competition effect which compensates the benefit stem from external R\&D unlike low-tech sectors. This effect would be higher in the case of knowledge-intensive service given that these firms show a small but negative coefficient of intra-industry externalities. This result would indicate that this type of firm reduce a little bit their productivity by the fact that all the other firms in its 


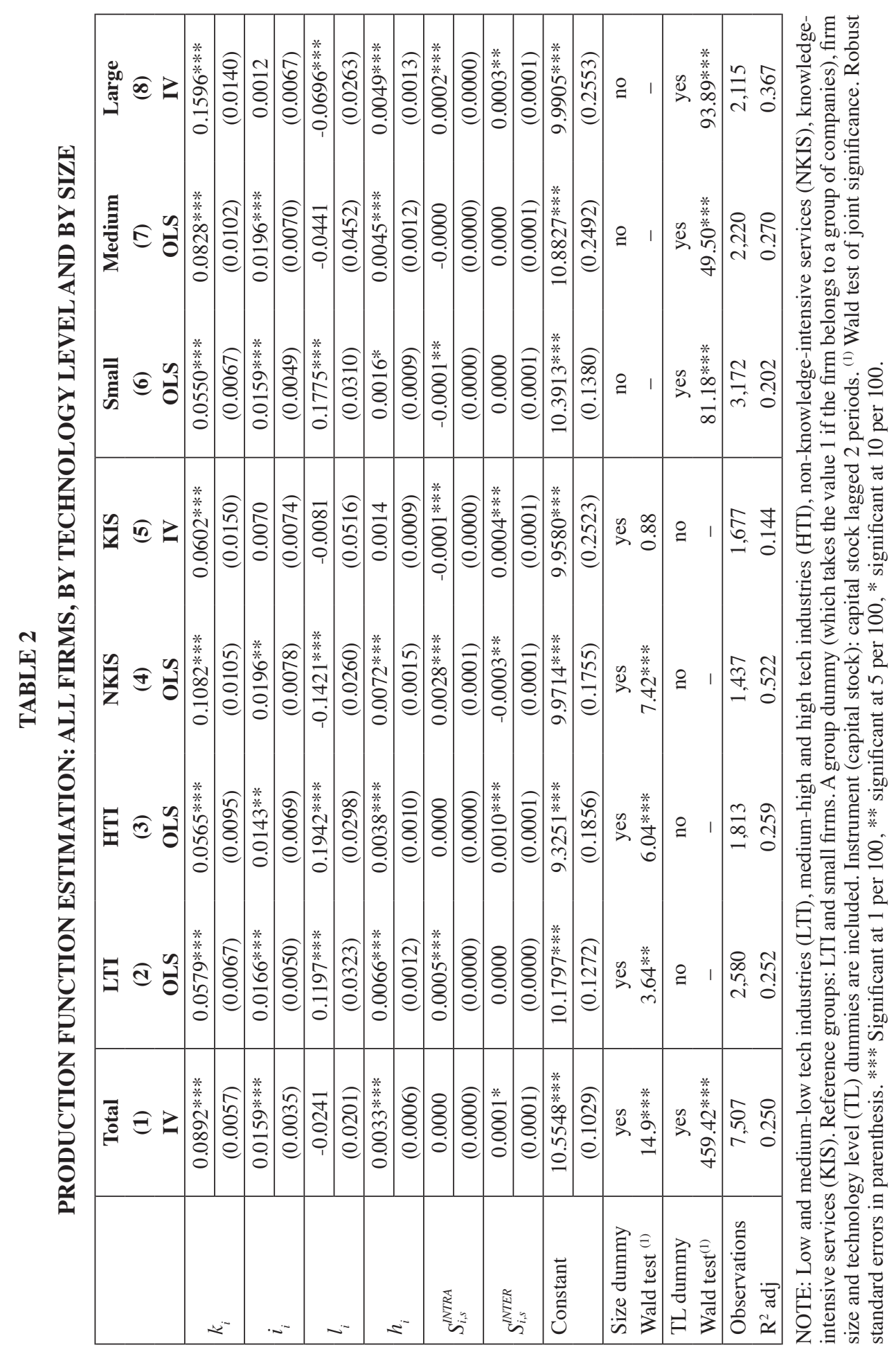


sector innovate, which may reflect a possible competition effect. In the breakdown by firm size the results suggest that the larger the firm, the more able to benefit from this external knowledge. Thus, R\&D expenditure carried out by all the other firms in the same sector has a negative impact on small firms, it is not relevant for medium-sized firms and its effect is positive for large firms. The negative coefficient obtained in small firms might be reflecting a competition effect between these kinds of companies.

With regard to inter-industry externalities, in the overall sample they are seen to present a positive sign (column 1). Hence it seems that exist some kind of sectoral complementarity given that the firm's productivity increase if the rest of the sectors that are its supplier raise their R\&D expenditures. When the sample is broken down according to technology level, it can be seen that these externalities are positive and significant for high-tech firms at both industry and service sectors (column 3 and 5). This result is consistent with the «absorption capacity» hypothesis put forward by Cohen and Levinthal (1989), which suggests that the degree to which firms benefit from external innovation is strongly dependent on its own innovation expenditure, with firms with greater technological capital being those that obtain the most benefit from externalities. By contrast, R\&D expenditure made by supplier sectors does not increase productivity in low-tech industries. Finally, non-knowledge-intensive services present a negative coefficient suggesting that firms which operate in this sector decrease their productivity if the rest of their supplier sectors increase their R\&D expenditure. This finding is unexpected and counterintuitive, since logically if supplier sectors innovate then the firm should either derive some benefit or none, but in no circumstances does it appear plausible that the firm would be harmed by this innovation. A possible explanation for this might be the great variety of sector typologies found within non-knowledge-intensive services, such as «postal and courier activities», «rental and leasing activities», and «activities of households as employers of domestic personnel». Unfortunately this implies a data limitation, since the PITEC classification does not allow for more detailed information on this aspect. Finally, in the breakdown by size sub-samples it can be seen that only large firms benefit from R\&D expenditure made by their supplier sectors. It can thus be suggested that there is a required «minimum size» given that only large firms are able to benefit from external innovation (either intra- or inter-industry externalities).

\section{Conclusions}

The aim of this paper was to study the extent to which technology level and firm size affect the return that firms obtain from their own investment in innovation and also from the innovation carried out by all other firms (both in the same sector and in other sectors). To this end a production function was used which included own R\&D expenditures and intra- and inter-industry externalities. The estimation method used was instrumental variables in order to take into account possible endogeneity 
problems and also ordinary least squares.

To recapitulate, we have seen in section III that there are significant differences between the technology level of the sector in which firms operate and firm size. Particularly, innovation effort is greater in advanced firms (both industry and service sectors). Moreover, the larger the firm, the less innovative is in relative terms. Human capital also presents notable difference according subsamples being much greater in high-tech and small firms. In order to take into account these factors, we estimate each sub-sample separately.

The results coincide with the previous literature since the impact of innovation is positive and statistically significant. Nevertheless, in contrast to earlier results, the impact of R\&D is greater for low-tech than high-tech firms. Similarly physical capital shows a positive impact which is also higher in less advanced firms, especially in the service sector. When comparing both variables it can be seen that the return from physical capital is greater than that from innovation independently of technology level and firm size. Concerning human capital, it must be stressed that it has a much greater impact in low-tech firms, as well as, medium-sized and large firms. However, it is not significant for firms belonging to knowledge-intensive services. As we mentioned before, this could be due to an over-education problem given that there are a high percentage of qualified employees who are not working according to their level of education.

As regards intra-industry externalities, only low-tech firms manage to benefit from the R\&D expenditure carried out by all the other firms in the same sector trying to make up for its smaller investment effort by taking advantage of innovation originating in firms in the same sector. This result points to the existence of a «technology threshold» beyond which firms cease to benefit from the investments in innovation carried out by all the other firms in the same sector. It is worth to mention that those firms belonging to knowledge-intensive services present a negative coefficient which could be suggesting a competition effect between them. As far as inter-industry externalities are concerned, it has been seen that they are positive and significant for high-tech firms in both industry and service sector. These results are in line with the absorption capacity hypothesis (Cohen and Levinthal, 1989) because the greater the technology capital of the sector in which the firm operates - as is the case of high-tech industries and knowledge-intensive services- the more advantage is obtained from inter-industry externalities. However, those firms belonging to non-knowledge-intensive services show a negative coefficient. This result may be explained by the fact that this sector is very heterogeneous and includes business ranging from «wholesale and retail» to «activities of extraterritorial organizations and bodies». Concerning firm size, the results show that only large firms benefit from external R\&D expenditures either made by the rest of the firms of its sectors or by those sectors that are its suppliers. Therefore, this finding suggests that a minimum firm size is needed in order to capture externalities. 


\section{References}

[1] ARVANITIS, S. and LOUKIS, E. N. (2009): «Information and communication technologies, human capital, workplace organization and labour productivity: a comparative study based on firm-level data for Greece and Switzerland», Information Economics and Policy, 21, 43-61.

[2] BENEITO, P. (2001): «R\&D productivity and spillovers at the firm level: evidence from Spanish panel data», Investigaciones Económicas, XXV, 289-313.

[3] BLACK, S. E. and LYNCH, L. M. (1996): «Human-capital investments and productivity», American Economic Association, 86, 263-267.

[4] CASSIMAN, B.; GOLOVKO,E. and MARTÍNEZ-ROS, E. (2010): «Innovation, exports and productivity», International Journal of Industrial Organization, 28, 372-376.

[5] CASTANY,L.; LÓPEZ-BAZO,E. and MORENO, R. (2009): «Decomposing differences in total factor productivity across firm size. The role of innovation and human capital», Working Paper IAREG No 5/11, AQR-IREA, University of Barcelona.

[6] COHEN, W. M. and LEVINTHAL, D. A. (1989): «Innovation and learning: the two faces of R\&D», Economic Journal, 99, 569-596.

[7] CREPON, B.; DUGUET, E. and MAIRESSE, J. (1998): «Research, Innovation and Productivity: An Econometric Analysis at the Firm Level», Economics of Innovation and New Technology, 7, 115-158.

[8] GOYA, E.; VAYÁ, E. and SURIÑACH, J. (2012): «Do intra- and inter- spillovers matter? CDM model estimates for Spain», Working Paper IREA 2012/14.

[9] GRIFFITH, R.; HUERGO, E.; MAIRESSE, J. and PETERS, B. (2006) Innovation and productivity across four european countries, Oxford Review of Economic Policy, 22, 483-498.

[10] GRILICHES, Z. (1979): «Issues in assessing the contribution of research and development to productivity growth», Bell Journal of Economics, 10, 92-116.

[11] GRILICHES, Z. (1986): «Productivity , R\&D, and basic research at the firm level in the 1970's», American Economic Association, 76, 141-154.

[12] GRILICHES, Z. (1992): «The search for R\&D spillovers», Scandinavian Journal of Economics, 94, 29-47.

[13] GUMBAU-ALBERT, M. and MAUDOS, J. (2006): «Technological activity and productivity in the Spanish regions», The Annals of Regional Science, 40, 55-80.

[14] HALL, B. H. and MAIRESSE, J. (1995): «Exploring the relationship between R\&D and productivity in French manufacturing firms», Journal of Econometrics, 65, 263-293.

[15] HALL, B. H.; LOTTI, F. and MAIRESSE, J. (2009): «Innovation and productivity in SMEs: empirical evidence for Italy», Small Business Economics, 33, 13-33.

[16] HALTIWANGER, J. C.; LANE, J. I. and SPLETZER, J. R. (1999): «Productivity differences across employers: the roles of employer size, age, and human capital», American Economic Association, 89, 94-98.

[17] HARHOFF, D. (1998): «R\&D and productivity in German manufacturing firms», Economics of Innovation and New Technology, 6, 29-50.

[18] HARHOFF,D.(2000): «R\&D spillovers, technological proximity, and productivity growthEvidence from German panel data», Schmalenbach Business Review, 52, 238-260.

[19] HUERGO, E. and JAUMANDREU, J. (2004): «Firms' age, process innovation and productivity growth», International Journal of Industrial Organization, 22, 541-559. 
[20] HUERGO, E. and MORENO, L. (2004): «La innovación y el crecimiento de la productividad en España», Ekonomiaz, 56, 208-231.

[21] JANZ, N.; LÖÖF, H. and PETERS, B. (2004): «Firm level innovation and productivityIs there a common story across countries?», Problems \& Perspectives in Managment, 2, 184-204.

[22] JAUMANDREU, J. (2009): «What explains the evolution of productivity and competitiveness? The innovation link», Working Paper No 804, IESE Business School, University of Navarra.

[23] KLETTE, T. J. (1994): «R\&D, spillovers and performance among heterogenous firms. An empirical study using microdata», Discussion Paper No 133, Statistics Norway.

[24] LEE, C. (2011): «Trade, productivity, and innovation: Firm-Level evidence from Malaysian Manufacturing», Journal of Asian Economics, 22, 284-294.

[25] LOS, B. and VERSPAGEN, B. (2000): «R\&D spillovers and productivity: evidence from U.S. manufacturing microdata», Empirical Economics, 25, 127-148.

[26] LOTTI, F. and SANTARELLI, E. (2001): «Linking knowledge to productivity: a Germany-Italy comparison using the CIS database», Empirica, 28, 293-317.

[27] LÓPEZ PUEYO, C. and SANAÚ VILLARROYA, J. (1999): «Tecnología y crecimiento: análisis en la industria española, 1986-1992», ICE Cambio Tecnológico y Competitividad, 781, 11-25.

[28] MAIRESSE, J. and SASSENOU, M. (1991): «R\&D and productivity: a survey of econometric studies at the firm level», Working Paper No 3666, NBER, Cambridge, MA.

[29] MATÉ-GARCÍA, J. J. and RODRÍGUEZ-FERNÁNDEZ, J. M. (2008): Productivity and R\&D: an econometric evidence from Spanish firm-level data», Applied Economics, 40, 1827-1837.

[30] MATÉ-GARCÍA, J. J. and RODRÍGUEZ-FERNÁNDEZ, J. M. (2002): «Crecimiento de la productividad e inversión en I+D: un análisis empírico de las empresas manufactureras españolas», Economía Industrial, 347, 99-110.

[31] NADIRI, M. I. (1993): «Innovation and techological spillovers», Working Paper No 4423, NBER, Cambridge, MA.

[32] OCDE (2001): Tableau de nord de l'OCDE de la Science, de la Technologies et de la industrie.

[33] ORTEGA-ARGILÉS, R.; PIVA, M.; POTTERS, L. and VIVARELLI, M. (2010): «Is Corporate R\&D Investment in High-Tech sectors more effective?», Contemporary Economic Policy, 28, 353-365.

[34] ORTEGA-ARGILÉS, R.; POTTERS, L. and VIVARELLI, M. (2011): «R\&D and productivity: testing sectoral peculiarities using micro data», Empirical Economics, 41, 817-839.

[35] PARISI, M. L.; SCHIANTARELLI, F. and SEMBENELLI, A. (2006): «Productivity, innovation and R\&D: micro evidence for Italy», European Economic Review, 50, 2037-2061.

[36] ROCHINA-BARRACHINA, M. E.; MAÑEZ, J. A. and SANCHIS-LLOPIS, J. A. (2010): «Process innovations and firm productivity growth», Small Business Economics, 34, 147-166.

[37] RODRÍGUEZ-FERNÁNDEZ, J. M. and MATÉ-GARCÍA, J. J. (2006): «Productividad del trabajo y continuidad en la inversión tecnológica: un análisis empírico en las empresas manufactureras españolas», Cuadernos de Economía y Dirección de Empresa, 27, 61-84. 
[38] SEGARRA-BLASCO, A. and TERUEL, M. (2011): «Productivity and R\&D sources: evidence for Catalan firms», Economics of Innovation and New Technology (iFirst).

[39] SEGARRA-BLASCO, A. (2007): «Innovation sources and productivity: a quantile regression analysis», Working Paper No 2007/08, XREAP.

[40] SEGARRA-BLASCO, A. (2010): «Innovation and productivity in manufacturing and service firms in Catalonia: a regional approach», Economics of Innovation and New Technology, 19, 233-258.

[41] TSAI, K.-H. and WANG, J.-C. (2004): «R\&D Productivity and the Spillover Effects of High-tech Industry on the Traditional Manufacturing Sector: The Case of Taiwan», The World Economy, 27, 1555-1570.

[42] TSANG, M. C.; RUMBERGER, R. W. and LEVIN, H. M. (1991): «The impact of surplus schooling on worker productivity», Industrial Relations, 30, 209-228.

[43] TURCOTTE, J. and RENNISON, L. W. (2004): «The link between technology use, human capital, productivity and wages: firm-level evidence», International Productivity Monitor, 9, 25-36.

[44] VERSPAGEN, B. (1995): «R\&D and Productivity: A Broad Cross-Section CrossCountry Look», The Journal of Productivity Analysis, 6, 117-135.

[45] WAKELIN, K. (2001): «Productivity growth and R\&D expenditure in UK manufacturing firms», Research Policy, 30, 1079-1090.

[46] YANG, C.-H.; LIN, C.-H. and MA, D. (2010): «R\&D, human capital investment and productivity: firm-level evidence from China's electronics industry», China \& World Economy, 18, 72-89. 


\section{APPENDICES}

\section{Appendix A \\ Treatment of extreme values}

The table below reports the number of firms with more than double the volume of sales by technology level. These observations have been replaced by the double of sales.

TABLE A1

OUTLIERS BY TECHNOLOGICAL LEVEL

\begin{tabular}{|l|c|c|c|c|c|}
\hline More than 2* Sales & LTI & HTI & NKIS & KIS & Total \\
\hline Investment intensity & 7 & 1 & 11 & 16 & 35 \\
\hline R\&D expenditures & 1 & 0 & 1 & 37 & 39 \\
\hline
\end{tabular}

TABLE A2

OUTLIERS BY FIRM SIZE

\begin{tabular}{|l|c|c|c|c|}
\hline More than 2* Sales & Small & Medium & Large & Total \\
\hline Investment intensity & 17 & 7 & 11 & 35 \\
\hline R\&D expenditures & 24 & 11 & 4 & 39 \\
\hline
\end{tabular}




\section{Appendix B \\ Correspondence table for branches of business activity}

TABLE B1

CORRESPONDENCE BETWEEN PITEC AND NACE-REV. 2 CLASSIFICATION

\begin{tabular}{|c|c|}
\hline Branches of business activity PITEC & NACE Rev. 2 \\
\hline \multicolumn{2}{|l|}{ Low-tech manufacturing industries } \\
\hline Manufacture of food products, beverages and tobacco products & $10,11,12$ \\
\hline Textile industry & 13 \\
\hline Wearing apparel & 14 \\
\hline Leather and related products & 15 \\
\hline Wood and products of wood & 16 \\
\hline Paper and paper products & 17 \\
\hline Printing and reproduction of recoded media & 18 \\
\hline Manufacture of furniture & 31 \\
\hline Other manufacturing & 32 \\
\hline \multicolumn{2}{|l|}{ Medium-low-tech manufacturing industries } \\
\hline Manufacture of rubber and plastic products & 22 \\
\hline Manufacture of other non-metallic mineral products & 23 \\
\hline Manufacture of basic metals & 24 \\
\hline Manufactured of fabricated metal products & 25 \\
\hline Building of ships and boats & 301 \\
\hline Repair and installation of machinery and equipment & 33 \\
\hline \multicolumn{2}{|l|}{ Medium-high-tech manufacturing industries } \\
\hline Manufacture of chemical and chemical products & 20 \\
\hline Manufacture of electrical equipment & 27 \\
\hline Manufacture of machinery and equipment & 28 \\
\hline Manufacture of motor vehicles, trailers and semitrailers & 29 \\
\hline Manufacture of other transport equipment & $30($ exc. 301, 303) \\
\hline \multicolumn{2}{|l|}{ High-tech manufacturing industries } \\
\hline Manufacture of pharmaceutical products and preparations & 21 \\
\hline Manufacture of computer, electronic and optical products & 26 \\
\hline Manufacture of air and spacecraft and related machinery & 303 \\
\hline \multicolumn{2}{|l|}{ Non-knowledge-intensive services } \\
\hline Trade & $45,46,47$ \\
\hline Transport and warehousing & $49,50,51,52,53$ \\
\hline Food service activities & 55,56 \\
\hline Real estate activities & 68 \\
\hline Administrative activities and auxiliary services & $77,78,79,80,81,82$ \\
\hline Other services & 95,96 \\
\hline \multicolumn{2}{|l|}{ Knowledge-intensive services } \\
\hline Telecommunications & 61 \\
\hline Programming and broadcasting activities & 62 \\
\hline Other information and communication services & $58,59,60,63$ \\
\hline Financial and insurance activities & $64,65,66$ \\
\hline Scientific research and development & 72 \\
\hline Other activities & $69,70,71,73,74,75$ \\
\hline Education & $85($ exc. 854$)$ \\
\hline Human health and social work activities & $86,87,88$ \\
\hline Arts, entertainment and recreation & $90,91,92,93$ \\
\hline
\end{tabular}

SOURCE: PITEC and Eurostat. 
Appendix C

Distribution of firms according sub-samples

TABLE C1

SAMPLE DISTRIBUTION

\begin{tabular}{|l|c|c|c|c|}
\hline & SMALL & MEDIUM & LARGE & Total \\
\hline LTI & 1,173 & 911 & 496 & 2,580 \\
\hline HTI & 881 & 589 & 343 & 1,813 \\
\hline NKIS & 393 & 313 & 731 & 1,437 \\
\hline KIS & 725 & 407 & 545 & 1,677 \\
\hline Total & 3,172 & 2,220 & 2,115 & 7,507 \\
\hline
\end{tabular}




\section{Appendix D \\ Construction of stock variables}

As it is commonly accepted in the literature ${ }^{18}$, productivity is affected by the cumulated stocks of physical capital and R\&D expenditure, instead of current flows. In order to construct these stocks we used the well-known perpetual inventory method:

$$
\begin{gathered}
K_{t}=K_{t-1} \cdot\left(1-\delta_{j}^{k}\right)+C_{t} \\
K_{0}=\frac{C_{0}}{g_{s}^{k}+\delta_{j}^{k}}
\end{gathered}
$$

and

$$
\begin{gathered}
I_{t}=I_{t-1} \cdot\left(1-\delta_{j}^{i}\right)+R D_{t} \\
I_{0}=\frac{R D_{0}}{g_{j}^{i}+\delta_{j}^{i}}
\end{gathered}
$$

with $t=2004, \ldots, 2010, j=1,2,3,4, s=1, \ldots, 38$.

where $C_{t}$ is the real investment in material goods and $R D_{t}$ is the real $\mathrm{R} \& \mathrm{D}$ expenditure ${ }^{19}$. We applied different depreciation rates according to the technological level ( $j$ ). Following Ortega-Argilés (2011), the more advanced the sector the faster technological progress which accelerates the obsolescence of the current physical capital and knowledge. Thus, we applied sectoral depreciation rates of 6 per 100 and 7 per 100 for the physical capital $\left(\delta_{j}^{k}\right)$ and 15 per 100 and 18 per 100 for innovation $\left(\delta_{j}^{i}\right)$ to low-tech and high-tech sectors respectively. Regarding the growth rates, if we used the first periods to computed them, we would have lost a large part of information given that our panel is short (2004-2010). For this reason, we decided to calculate $g_{s}^{c}$ and $g_{s}^{i}$ as an average rate of change in real investment in material good and real R\&D expenditure in each sector $(s)$ over the period $1995-2003^{20}$. We used the OECD ANBERD to calculate physical capital growth rates $\left(g_{s}^{c}\right)$ and the OECD STAN databases for innovation growth rates $\left(g_{s}^{i}\right)$.

${ }^{18}$ See HALL and MAIRESSE (1995), BÖNTE (2003) and ORTEGA-ARGILES et al. (2011) to name a few.

${ }^{19}$ Both of them are in constant values at 2000 base prices. Nominal values have been deflated using the GDP deflator.

${ }^{20}$ At any rate, the choice of $g$ does not considerably modify the results. As HALL and MAIRESSE (1995) mention: «In any case, the precise choice of growth rate affects only initial stock, and declines in importance as time passes...». 